Review Article

\title{
The Epidemiology and Economics of the Pandemic COVID-19: Heading towards a Doomsday Syndrome-A Global Recession
}

\section{Raghuram S Kudligi}

Bharatiya Vidya Bhavan.

DOI: https://doi.org/10.24321/2455.7048.202017

\section{I $\quad \mathbf{N} \quad \mathbf{F} \quad \mathbf{O}$}

E-mail Id:

dr.raghuramks@outlook.com

Orcid Id:

https://orcid.org/0000-0002-5876-1182

How to cite this article:

Kudligi RS. The Epidemiology and Economics of the Pandemic COVID-19: Heading towards a Doomsday Syndrome-A Global Recession. Epidem Int 2020; 5(2): 47-52.

Date of Submission: 2020-04-19

Date of Acceptance: 2020-06-12

\section{$\begin{array}{llllllllllllll}\mathbf{A} & \mathbf{B} & \mathbf{S} & \mathbf{T} & \mathbf{R} & \mathbf{A} & \mathbf{C} & \mathbf{T}\end{array}$}

The year 2020 started with an impending disaster believed to be carried forward from China since Nov-Dec 2019 and today, virtually, no country is spared that led to the global lockdown amounting to cumulative output losses to a tune of USD 9 trillion. This paper carries out an epidemiological review of literature, attempts to simulate and replicate previous health crisis episodes and their impact on the global economy. It also analyses the concurrent events and shocks associated with the financial and economic downsides due to the global pandemic leading to a global recession, which the IMF predicts to be bigger than the Great Depression of 1930. Extensive articles from primary and secondary sources are referred to analyze the Case Fatality Ratio (CFR) and the impact of COVID-19 on the stock market trends. The paper also attempts to simulating previous shocks associated with recessions to the current situation, estimate the economic damage and concludes with possible alternatives available to governments apart from flattening the curve.

Keywords: COVID-19, Coronavirus, Case Fatality Ratio (CFR), Recession, Doomsday Syndrome, China Wet-Markets

\section{Introduction}

Guan Yi, a professor of infectious diseases at the University of Hong Kong, who also was a team member which identified the coronavirus that caused SARS, insists to have answers to four fundamental questions before successfully treating any viral disease. The questions are, "What is it? What does it do? Where does it come from? And how do you kill it?"1 This pandemic started with mysterious pneumonia. By the end of January 2020, this pneumonia was declared to be caused by a virus that resembles the infective agent that caused Severe Acute Respiratory Syndrome (SARS) and the Middle East Respiratory Syndrome Coronavirus (MERS-CoV). This virus was identified as a novel Coronavirus (nCoV) also called Severe Acute Respiratory Syndrome Coronavirus-2 (SARS-CoV-2) which belongs to the genus Coronavirus in the Coronaviridae. ${ }^{2}$

All CoVs are pleomorphic RNA viruses characteristically containing crown-shape peplomers with 80-160 nM in size and $27-32$ kb positive polarity. ${ }^{3}$ This paper dwells into the specific factors that led to this epidemic, the case fatality analysis of coronaviruses and its family, and the impact on the healthcare and global economy.

\section{Materials and Methods}

An attempt is made to review relevant and systematic review of literature that provides evidence to why such pandemics and epidemics originate from China, healthcare system 
In China. The incidence and impact of these diseases are analyzed along with their relative global economic impact. The latest reports as of $17^{\text {th }}$ Apr 2020 from the World Health Organization (WHO), International Monetary Fund (IMF) and World Bank are consulted.

\section{Epidemiology}

The origin of the novel Coronavirus (nCoV) traces to wet animal markets in China. Preliminary studies presume that the nCoV transmitted from animals found in the wet markets to humans The basis for this presumption is that earlier episode of coronavirus (like SARS) has been transmitted from civets. Another supporting evidence is that early COVID infected patients worked in the wet markets of Wuhan, China. Researchers demonstrate almost $96 \%$ of the DNA resembles that of bat and humans. But initial findings do not support the presence of a direct link to humans but it is transmitted through an intermediate host. Pangolins from the wet markets in China were believed to be the intermediate hosts, but still, there is no conclusive evidence to prove this. ${ }^{4}$

China is known globally for its exotic meat markets, its typology and hygiene in these wet markets. Dr. Steven Novella recently opined on an episode of the Skeptics' Guide to the Universe, "It's not a big mystery why this is happening... lots of concentrated population, with intimate contact with lots of species of animals that are potential reservoirs, and they don't have great hygiene required. It's a recipe for spitting out these kinds of viruses." 5

Likewise, India is also known to be equally populated and with clustered contacts and events, like the ones of the world's largest spiritual gathering - the Ardh Kumbh in Prayag (Allahabad) from January 15 to March 4, 2019, where a whopping 150 million people attended. This count of people exceeds the population of 100 countries combined. ${ }^{6}$

\section{Case Fatality Ratio and Previous Episodes}

Case Fatality Ratio: The starting point for any government or health care department is to understand the Case Fatality Ratio (CFR), although estimating this is very challenging. The case-fatality ratio is the proportion of the number of deaths caused by the disease to the number of confirmed cases of the disease. CFR differs slightly from the Infection Fatality Rate (IFR). IFR is the ratio of deaths among all infected cases (not necessarily diagnosed cases). IFR includes undiagnosed infections and individuals who are asymptomatic. Since the denominator is greater in IFR, CFR tends to be higher than IFR. One more challenge in CFR is that it seldom stays constant. It is very volatile and varies from time to time and location to location. In China alone at the start of the outbreak WHO reported a higher CFR of $17.3 \%$ across China and $20 \%$ in Wuhan, the epicenter of the disease. Later a gradual reduction in CFR was observed as the infection increased in China. It is also worth-while to note that many countries downplayed initially this pandemic as seasonal influenza. In a study conducted by Shigui Ruan during April 2020 reported that although the CFR is as low as 1.6\% for people suffering from COVID-19 under the age group below 29 , it is three times more than the CFR when compared to seasonal influenza. ${ }^{7}$

As per Lazzerini and Putoto (2020) also confirmed that the CFR is very dynamic and no disease has a fixed pattern of CFR. They reported that CFRs differ largely from one country to another. They observed CFR was $0.2 \%$ in Germany and went up to $7.7 \%$ in Italy. One reason is that there is no ratification for the cases being symptomatic or asymptomatic and differences in testing procedures adopted by different countries due to the absence of standardized testing practice. Research published in the Chinese Journal of Epidemiology, 2020 suggests that the CFR for infected people with comorbidities is higher than the normal infected person. They reported that COVID-19 infected patients with cardiovascular diseases, the CFR was more than $10 \%$, and the patients who had diabetes and hypertension ${ }^{8}$ the CFR was also higher. Table 1 shows the similarities and variations of CFR and other vital parameters of coronaviruses.

Table I.Similarities and dissimilarities of coronaviruses

\begin{tabular}{|c|c|c|c|}
\hline & SARS & MERS & COVID-19 \\
\hline Pathogen & SARS-CoV & MERS-COV & SARS-CoV-2 \\
\hline CFR & $10.00 \%$ & $34 \%$ & $1.3-3.4 \%$ \\
\hline Transmission & \multicolumn{3}{|c|}{ Droplets produced by coughing, sneezing, talking, or breathing } \\
\hline Mean Incubation period & \multicolumn{3}{|c|}{5 days } \\
\hline Key Symptoms & \multicolumn{3}{|c|}{ A cough (dry at first), a fever } \\
\hline Other Symptoms & Diarrhea & \multicolumn{2}{|c|}{ Shortness of breath } \\
\hline At-risk & \multicolumn{3}{|c|}{ People with pre-existing medical conditions } \\
\hline Treatment & \multicolumn{3}{|c|}{ No Specific treatment } \\
\hline Vaccine & \multicolumn{3}{|c|}{ No } \\
\hline
\end{tabular}

Source: Eastern Mediterranean Health Journal, ${ }^{9}$ US Centers for Disease Control and Prevention (CDC $)^{10 \text { and }}$ World Health Organization (2020). ${ }^{11}$ 


\section{Previous Episodes}

About 4 million people were killed during Asian Flu in 1956 and Hong Kong Flu of 1968 which either originated or passed through China. Again in 2002, Severe Acute Respiratory Syndrome (SARS) originated in mainland China's exotic meat markets of Guangdong province and spread to many continents. SARS infected 8000 plus people and recorded close to 800 casualties in about 17 counties globally. ${ }^{12} \mathrm{China}$ initially downplayed the magnitude of the SARS outbreak. Global health bodies and administrators condemned China for doing so. ${ }^{13}$

According to an article in CNBC, SARS eliminated close to 0.5 to $1 \%$ of China's GDP in 2003. Again in China, the H7N9 influenza virus transmitted from poultry to humans in 2013. There were 5 iterations of this virus, the last one being most fatal with around 1500 confirmed cases, ${ }^{14} \mathrm{As}$ I write this paper, the latest pandemic believed to have originated from Central Chinese City of Wuhan province, COVID-19 has already sickened more than 2.03 million confirmed cases and more than a hundred and thirty-five thousand casualties across the globe over 200 countries and still counting. As per WHO chief, Dr. Tedros Adhanom Ghebreyesus "It took 67 days from the first reported case to reach the first 100,000 cases, 11 days for the second 100,000 cases and just four days for the third 100,000 cases. ${ }^{\prime 15}$ Countries have been trying to put their best foot forward to win the war over this invisible enemy but look like they are far from over, barring a few countries like South Korea and Greece. Attempts from the countries which have the best healthcare systems to flatten the curve of the confirmed case have yielded little or no results at least in the initial stages of the outbreak. No mathematical model or algorithm has been able to predict the number of people that may succumb to this infection.

\section{Coronavirus Impact on the Economy}

The dawn of 2018 had a downward prediction of global GDP by the world bank but certainly not a global recession. There are pieces of evidence from the recent past that global slowdown or a recession occurs when a global hypothesis will have a negative outcome. We have analogies from the past, one during 2001, the hypothesis was that the Information and communication technology would jack up the capital markets and global economy, others during 2007, it was hypothesized that the real estate would boom both in the short and long-run. Sequel to the above, recession is an outcome of two factors happening in a sequence, the precursor is a sluggish economy that is compounded by a major event. We have witnessed this during the previous two recessions episodes one during 2001-02 and the other in 2007-08. The dot.com bubble burst was compounded by twin towers attack in the US (9/11). The real estate markets' bust sub-prime crisis. ${ }^{16}$
Applying the same analogy, the trade war between the US and China, Brexit, sluggish GDP growth in the European Union and Chinese economy contraction. The US market, in particular, is very buoyant with increased import costs and tax rate cuts. China is currently witnessing a growth rate of $4.8 \%$ which is lowest in the last 3 decades. Germany is on the verge of a slowdown due to the sluggish manufacturing sector. Its economy reduced by $0.1 \%$ with 2 quarters recording sub-zero growth in succession. UK growth contracted $0.2 \%$ was particularly staring at a nodeal and hard-Brexit. Italy is facing political turmoil, lower productivity, and a high unemployment rate. Argentina and Brazil doing no better. Singapore and South Korea also recorded a slump in their growth rates. Owing to these scenarios IMF estimated that the global economy will grow at 3\% which is the slowest growth rate since the 2008 recession. From the World bank data real GDP forecasts and estimates, it is evident that 2020 forecasts for the world $-0.2 \%$ growth from 2019 and it is estimated a negative growth for most countries. All of these compounded with the sudden outburst of COVID-19 is accelerating the globe towards a recession? ${ }^{17}$

As per IMF, the rate of global growth is set to fall to -3 percent. It has also predicted that the current crisis will be the worst since the great depression since 1930. IMF has called this "the great Lockdown". It also predicts that cumulative output losses during 2020 and 2021 will be around USD 9 trillion. ${ }^{18}$

Markets started to tumble when the virus started to spread across Europe. There is hardly any algorithm or formula that precisely predicts the virus trajectory and the GDP forecasts and economic impact of the disease.

The market sentiments and vulnerability have let to a sharp contraction. Many countries including the G7 countries that control almost three fourth of the global economy have declared emergencies. They are already in the damage model and initiated measures to strengthen their fiscal and monetary policies and provide liquidity in the markets. Many countries including the US Federal Reserve has announced massive stimulus packages. While the current economic trajectory does not support a policy-induced recession but is certain of a real recession which may be harder than the 2008-09 recession. Global demand and supply are affected due to the contraction and disruption of supplychains ${ }^{19}$ Guy Ryder, ILO Director-General says "This is no longer only a global health crisis, it is also a major labor market and economic crisis that is having a huge impact on people" The International Labour Organization (ILO) has indicated that there is a possibility of 25 million job losses due to sluggish growth. However, it has also hinted that major damage can be averted if there is an internationally co-ordinated policy response similar to the one initiated during the 2008-09 recession. 
The ILO envisages with the current global health and economic crisis there could range unemployment anywhere between 5.3 million ("low" scenario) and 24.7 million ("high" scenario). As a result of this job loss, ILO also predicts loss in income to the employees to the tune of $\$ 860$ billion and $\$ 3.4$ trillion by the end of $2020 .^{20}$

Brooking institute's Sifan Lu and Joseph Parilla (2020) forecast that the current slowdown is likely to grossly vary in gravity and timespan when compared to the 2008-09 recession that was triggered by a financial crisis. In the US during 2008-09, small businesses ' job loss accounted for $62 \%$ of job losses whilst its proportion to the total employment was only $45 \%$. They predict that the COVID-19 induced recession will be more disproportionate. ${ }^{21}$

By connecting the dots of researches of HBR, ILO, and Brooking institutes, there must be massive job losses resulting in a contraction with demand and supply disruptions. Retail businesses are likely to take the initial hit due to reduced demands as a result of lower disposable incomes due to job losses. This leads to consumer and corporate demands fall resulting in a domino effect to a real recession.

Philipp Carlsson-Szlezak, et al. (2020) of the BCG reported in Harvard Business Review that this recession is likely to follow a V-shaped rather than a U or L shaped. Historically, economies have followed a V-shaped pattern experiences a dip and later recovers. This was the pattern during SARS, Hong Kong Flu, Asian Flu, and Spanish Flu. ${ }^{22}$
The IMF had to revise its estimates post the outbreak of the pandemic.

The above table compares the World Bank and IMF predictions of GDP of Advanced Economies and Emerging Economies. The forecasts have to be revised by significantly downgrading the GDP due to the impact of the COVID-19 and global lockdown. It is clear from the above tables that barring China and India, most of the advanced and emerging economies have negative growth projections. As per the World Bank and IMF, this is the first time that both the advanced economies and emerging economies are at the recession and the growth projections were revised.

\section{Discussion and Conclusion}

The future is very uncertain given the epidemiology of SARS CoV-2 virus and the global lockdown leading to the recession. There are global disruptions to supply chain and restrictions to travel and socializing. Although countries are advocating social distancing, the general population at large is in a state of nervousness and anxiety that they or their loved ones may be infected by the virus and the fear of financial instability due to economic contractions. While the health care systems of the countries have been put to test and exposed the deficiencies and weaknesses of its health care infrastructure and health care systems.

Till the time researchers come out with a groundbreaking vaccine for the virus, governments globally have to resort to scaling up testing and isolation of positive cases, social

Table 2.Earlier and revised GDP estimates by the IMF and World bank

\begin{tabular}{|c|c|c|c|c|c|c|}
\hline \multicolumn{9}{|c|}{ Real GDP } \\
\hline & \multicolumn{3}{|c|}{ Earlier Forecast } & \multicolumn{3}{c|}{ Revised Forecast } \\
\hline Percent change from previous year & $\mathbf{2 0 1 9 e}$ & $\mathbf{2 0 2 0 f}$ & $\mathbf{2 0 2 1 f}$ & $\mathbf{2 0 1 9 a}$ & $\mathbf{2 0 2 0 f}$ & $\mathbf{2 0 2 1 f}$ \\
\hline World & 2.4 & 2.5 & 2.6 & 2.9 & -3 & 5.8 \\
\hline Advanced Economies & 1.6 & 1.4 & 1.5 & 1.7 & -6.1 & 4.5 \\
\hline United States & 2.3 & 1.8 & 1.7 & 2.3 & -5.9 & 4.7 \\
\hline Euro Area & 1.1 & 1 & 1.3 & 1.2 & -7.5 & 4.7 \\
\hline Japan & 1.1 & 0.7 & 0.6 & 0.7 & -5.2 & 3 \\
\hline China & 3.5 & 4.1 & 4.3 & 3.7 & -1 & 6.6 \\
\hline India & 6.1 & 5.9 & 5.8 & 6.1 & 1.2 & 9.2 \\
\hline Russia & 5 & 5.8 & 6.1 & 1.2 & 1.9 & 7.4 \\
\hline Brazil & 1.2 & 1.6 & 1.8 & 1.3 & -5.5 & 4.2 \\
\hline Mexico & 1.1 & 2 & 2.5 & 1.1 & -5.3 & 2.9 \\
\hline Saudi Arabia & 0 & 1.2 & 1.8 & -0.1 & -6.6 & 3 \\
\hline
\end{tabular}

Source: World Bank. And IMF World Economic Outlook. April 2020.

Global Economic Prospects January 2020 GDP growth data. ${ }^{23}$

Note: PPP = purchasing power parity; $a=$ actual, $e=$ estimate; $f=$ forecast. World Bank forecasts are frequently updated based on new information. 
distancing, and lockdowns when there is a resurgence of this infectious virus. In a scenario of non-availability of vaccine soon there may be a significant surge in fatalities rates when the lockdown policies end and economies open and commercial activities are up and running. Another scenario is to pray for herd immunity given the curve is not flattened. Humanity has witnessed and survived through many epidemics and pandemics like Plague, Cholera and Spanish Flu that had hundred and thousands of fatalities. Mankind will see this killer coronavirus also through. Children will get back to school, People will get back to offices, malls, theaters, and restaurants once humanity wins over the virus.

\section{Conflict of Interests: None}

\section{References}

1. Greenfeld KT. China syndrome: The true story of the 21st century's first great epidemic. Harper Perennial. 2007.

2. Ruan S. Likelihood Of Survival Of Coronavirus Disease 2019. Available from: https://www.thelancet.com/ journals/laninf/article/PIIS1473-3099(20)30257-7/ fulltext [Accessed 10 April 2020].

3. Woo P, Huang Y, Lau S, Yuen K. Coronavirus genomics and bioinformatics analysis. Omics in Clinical Practice 2014; 325-348. https://doi.org/10.1201/b17137-17 [Accessed 10 April 2020].

4. Cyranoski D, Mystery deepens over animal source of coronavirus. Nature 2020; 579(7797): 18-19. Available from: https://www.nature.com/articles/d41586-02000548-w.

5. https://www.theskepticsguide.org/podcasts, 2020. Https://Www.Theskepticsguide.Org/Podcasts.

6. Online F. Kumbh Mela 2019: Whopping 150 Million Expected To Attend, Greater Than Population Of 100 Countries Combined. [online] The Financial Express. 2020. Available at: <https://www.financialexpress. com/india-news/kumbha-mela-2019-whopping-150million-expected-to-attend-greater-than-populationof-100-countries-combined/1417572/> [Accessed 10 April 2020].

7. https://www.thelancet.com/journals/langlo/article/ PIIS2214-109X(20)30110-8/fulltext COVID-19 in Italy: momentous decisions and many uncertainties. Shigui Ruan. The Lancet Global Health 2020.

8. Lazzerini M, Putoto G. Epidemiological group of emergency response mechanism of new coronavirus pneumonia in Chinese Center for Disease Control and Prevention. Epidemiological characteristics of new coronavirus pneumonia. Chinese Journal of Epidemiology 2020; 41(2020-02-17).

9. Venkatesh S, Memish ZA|. SARS: the new challenge to international health and travel medicine. $E M H J-$
Eastern Mediterranean Health Journal 2004; 10(4-5): 655-662.

10. US Centers for Disease Control and Prevention (CDC). Influenza Burden, 2018-19.

11. Shultz JM, Espinel Z, Espinola M, Rechkemmer A. Distinguishing epidemiological features of the 2013-2016 West Africa Ebola virus disease outbreak. Disaster Health 2016; 3(3): 78-88. and World Health Organization (2020). Ebola virus disease: Factsheet.

12. Who.int. 2020. COVID-19 Situation Reports. [online] Available at: <https://www.who.int/emergencies/ diseases/novel-coronavirus-2019/situation-reports> [Accessed 14 April 2020].

13. Nytimes.com. 2020. China Identifies New Virus Causing Pneumonialike IIIness. [online] Available at: <https://www.nytimes.com/2020/01/08/health/chinapneumonia-outbreak-virus.html> [Accessed 10 April 2020].

14. Melinda Liu, Y., 2020. Is China Ground Zero For A Future Pandemic?. [online] Smithsonian Magazine. Available at: <https://www.smithsonianmag.com/science-nature/ china-ground-zero-future-pandemic-180965213/> [Accessed 12 April 2020].

15. Who.int. 2020. COVID-19 Situation Reports. [online] Available at: <https://www.who.int/emergencies/ diseases/novel-coronavirus-2019/situation-reports> [Accessed 14 April 2020].

16. How the recession of 2020 could happen. The New York Times - Breaking News, World News \& Multimedia. https://www.nytimes.com/2019/08/17/ upshot/how-the-recession-of-2020-could-happen.html [Accessed 05 April 2020].

17. Inman P. Is a global recession coming? Here are seven warning signs. the Guardian. https://www.theguardian. com/uk-news/2019/aug/25/is-a-global-recessioncoming-here-are-seven-warning-signs [Accessed 05 April 2020].

18. The great lockdown: Worst economic downturn since the Great Depression. (2020, April 14). IMF Blog. https://blogs.imf.org/2020/04/14/the-greatlockdown-worst-economic-downturn-since-the-greatdepression/ [Accessed 15 April 2020].

19. What coronavirus could mean for the global economy. Harvard Business Review. https://hbr.org/2020/03/ what-coronavirus-could-mean-for-the-global-economy [Accessed 15 April 2020].

20. https://www.aa.com.tr/en/economy/un-body-warnsof-up-to-25m-job-losses-due-to-covid-19/1771040.

21. Liu S, Parilla J. What the Great Recession can tell us about the COVID-19 small business crisis. Brookings. https:// www.brookings.edu/blog/the-avenue/2020/03/25/ what-the-great-recession-can-tell-us-about-the-covid- 
19-small-business-crisis/ [Accessed 12 April 2020].

22. Harvard Business Review, 2020. What Coronavirus Could Mean for the Global Economy. [online] Available at: <https://hbr.org/2020/03/what-coronavirus-couldmean-for-the-global-economy $>$ [Accessed 12 April 2020].

23. Payments B. IMF: World Economic Outlook (WEO), April 2020 - Knoema.Com. [online] Knoema 2020. Available at: <https://knoema.com/IMFWEO2020Apr/imf-worldeconomic-outlook-weo-april-2020> [Accessed 15 April 2020]. 